\title{
Trade Balance and Exchange Rate: The J-Curve
}

\author{
Dr. Ioannis N. Kallianiotis ${ }^{1}$
}

\begin{abstract}
The objective of this paper is to test empirically the effect of a devaluation of a currency on the trade account of the country, the J-curve effect, by using the trade between the U.S. and six countries (Euro-zone, Canada, United Kingdom, Switzerland, Japan, and Australia). A devaluation (depreciation) of the U.S. dollar is increasing the spot exchange rate $(\$ / F C)$ and increases the price of imports and reduces the price of exports. Then, imports are falling and exports are increasing and the trade account is improved in the long-run. In the short-run, the trade account is deteriorated because imports are pre-arranged and continue to increase with the higher spot rate. This J-curve hypothesis is tested by using a regression and a VAR model, where the volatility of the real exchange rate (TOT) is specified with a GARCH-M process. The empirical results mostly are supporting the J-curve effect.

JEL classification numbers: E4, F31, F32, F47, G14, G15.

Keywords: Demand for Money and Exchange Rate, Foreign Exchange, Current Account Adjustment, Forecasting and Simulation, Information and Market Efficiency, International Financial Markets.
\end{abstract}

\footnotetext{
${ }^{1}$ Economics/Finance Department, The Arthur J. Kania School of Management, University of Scranton, Scranton, PA 18510-4602, U.S.A.
}

Article Info: Received: January 11, 2022. Revised: January 27, 2022.

Published online: February 1, 2022. 


\section{Introduction}

A continuing trade deficit is detrimental to the nation's economy because it affects negatively production, employment, income, competitiveness, independence, and causes reductions of foreign assets at the Fed, because are used in financing the trade deficits, which are foreign currencies, SDRs, gold or debt. A country can buy more goods from abroad than it makes domestically by borrowing from its trading partners. This can only continue as long as the lending country trusts the borrowing one to repay the loan. One day, the lending countries might decide to ask the borrower to repay not only the interest, but the entire debt, which could generate serious effects in the domestic economy. ${ }^{2}$ However, this is not likely to happen because it would have adverse effects (depreciation) on those countries' currencies and imports will fall and trade will be reduced, which will deteriorate lender economy. Another concern for the trade deficit is about the competitiveness of the deficit country's economy itself. By purchasing goods overseas for a long enough period, the companies of the country lose their expertise, the workers their specialization, and even the factories ${ }^{3}$ the knowhow of making those products. As a nation loses its competitiveness, it outsources more jobs, more companies, and more income, which reduce its standard of living. Countries must be self-sufficient and in an autarky situation and this many times depends on domestic public and trade policies.

Countries can use trade policies (like, devaluation of their currencies, etc.) to reduce the trade account deficits, given that the Marshall-Lerner condition holds (elastic domestic and foreign demands for imports). Devaluation increases the price of imports and reduces the price of exports and due to the law of demand, imports are falling and exports are increasing and the trade account is improved. Let us start with a country that has a trade account deficit and decides to devaluate (depreciate) its currency to reduce the deficit, as it appears in Figure 1. At time $t_{1}$, the depreciation of the domestic currency takes place and a further deterioration in the trade balance occurs and gradually the trade balance improves, after time $t_{2}$; this path of adjustment takes the shape of a " $\mathrm{j}$ " and for this reason it called the J-Curve adjustment.

In the current period $\left(t_{1}\right)$, a sudden unexpected depreciation of the domestic currency has the following impact, due to the contracts for exports and imports, which are already in effect. Most of the imports are priced in foreign currencies. Thus, a sudden depreciation of the U.S. dollar will cause an increase in the trade deficit after time $t_{1}$ because the cost of imports will be higher in dollars, due to its depreciation, while the revenue from exports will remain unchanged because of the already existing export contracts. As the time is passing, the price of imports is increasing and imports are falling, but the price of exports might fall (the price of imported raw material or other inputs for their production will increase) and we will

${ }^{2}$ It might make its debt unsustainable. See, (Kallianiotis, 2018, p. 164).

${ }^{3}$ See, Niko J. Kallianiotis, America in a Trance. https://www.nikokallianiotis.com/book. 
reach period $t_{2}$, where the trade account is improving, due to reduction of imports and increase to exports. After time $t_{2}$, the trade account becomes positive (in surplus).

$S \uparrow(\$ \downarrow) \Rightarrow(M \uparrow \text { and } \bar{X})_{S-R} \Rightarrow T A_{S-R} \downarrow$ (int ernationaltradetransactions are pre-arranged and cannotadjust)

$\Rightarrow(M \downarrow \text { and } X \uparrow)_{L-R} \Rightarrow T A_{L-R} \uparrow\left(M^{d}\right.$ and $M^{s}$ are more inelasticin the short-run than in the long - run)

where, $\mathrm{S}=$ spot exchange rate, $\mathrm{M}=$ imports, $\mathrm{X}=$ exports, and $\mathrm{TA}=$ trade account.

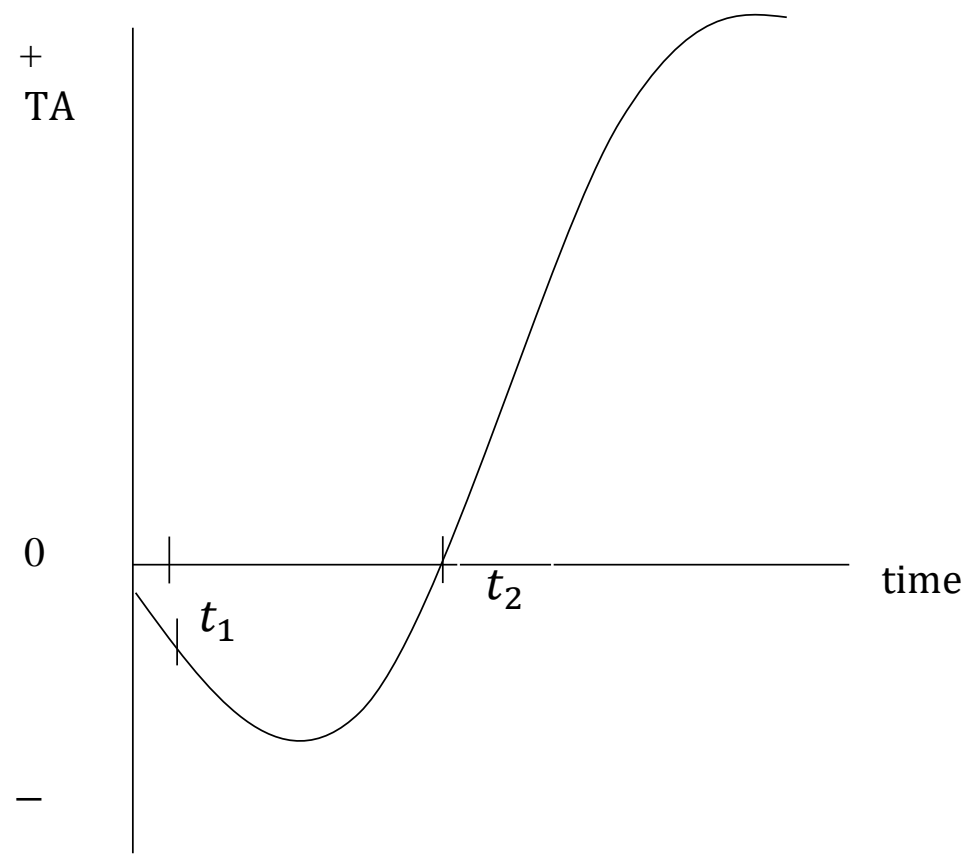

Figure 1: The J- Curve (TA Adjustment)

Note: $t_{1}=$ depreciation of the domestic currency period and $t_{2}=$ TA improvement period.

The adjustment of the trade balance takes place over a prolonged period of time. In some industrial countries the total time elapsing between the time of the depreciation of the currency and the improvement of the trade account varies between 3 to 12 months. For example, a depreciation the U.S. dollar will have the following effects on its trade account:

$T A_{t_{1}}<0 \Rightarrow S \uparrow(\$ \downarrow) \Rightarrow \bar{X}-M \uparrow=\left(\bar{P}_{X}^{\$} \bar{Q}_{X}\right)-\left(S_{\$ / \text { euro }} \uparrow \bar{P}_{M}^{\text {euro }} \bar{Q}_{M}\right) \Rightarrow T A \downarrow \downarrow$

where, $\mathrm{P}_{\mathrm{X}}=$ price of exports, $\mathrm{Q}_{\mathrm{X}}=$ quantity of goods exported, $\mathrm{P}_{\mathrm{M}}=$ price of imports, and $\mathrm{Q}_{\mathrm{M}}=$ quantity of goods imported. 
With the passing of time the current contracts will mature and the new contracts will be written with the new prices, which will reflect the changes of cost, due to the depreciation of the currency and the trade account ${ }^{4}$ will be improved because imports will fall and exports will increase. The objective of this study is to test the J-curve hypothesis by using a regression and a vector autoregression (VAR) model based on the trade account variables and the exchange rate volatility by applying a GARCH specification.

${ }^{4}$ The U.S. Current and Trade Account Deficits.

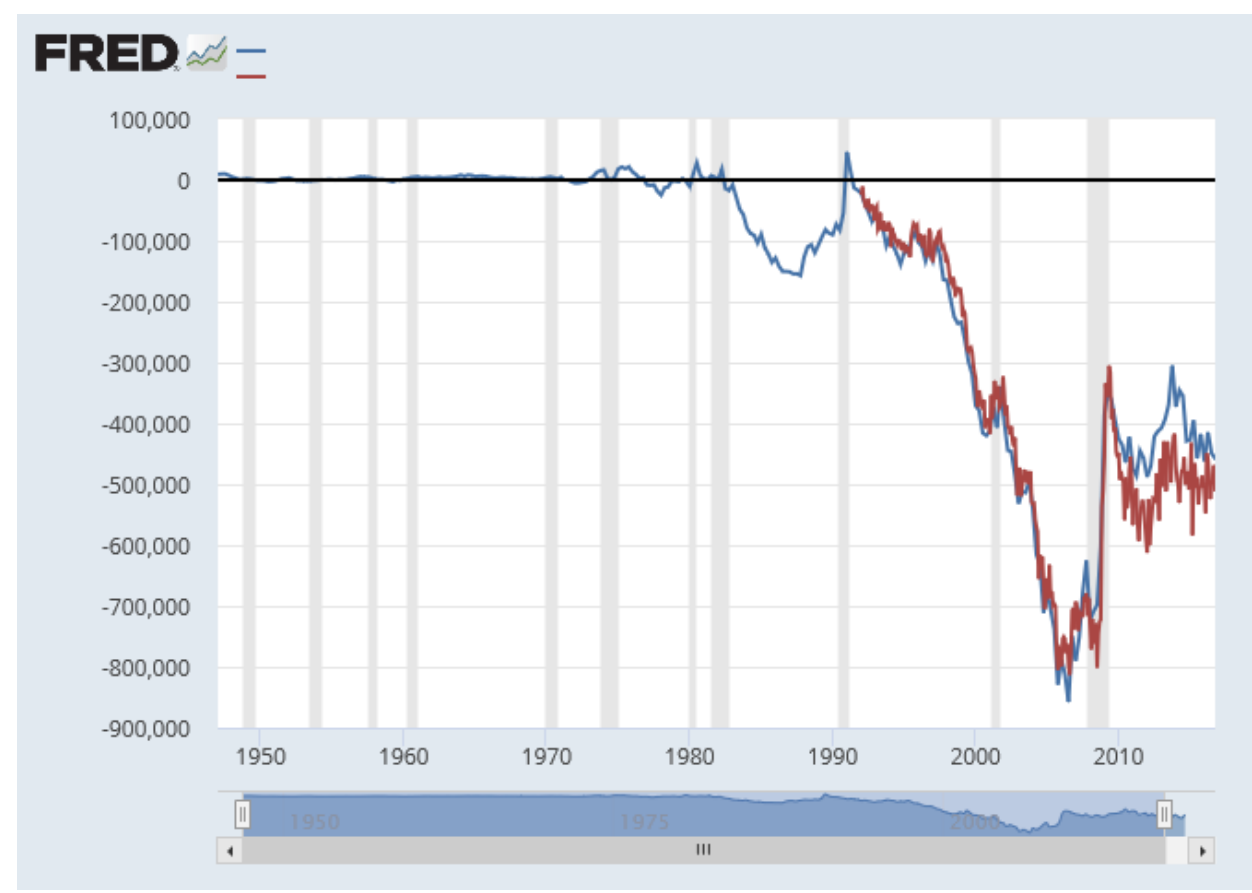

\section{Graph 1: Current Acount and Trade Balance}

Note: -----Blue line: Balance of CA (goods and services) and ----- Red line: Trade balance (goods). Source:https://fredblog.stlouisfed.org/2017/02/demystifying-the-tradebalance/?utm_source=series_page\&utm_medium=related_content\&utm_term=related_resources\& utm_campaign=fredblog. 


\section{Theoretical Model Specification}

As it was mentioned, countries can use trade policies (the traditional, like, tariffs, import taxes, and quota or the less reactionary one, devaluation of their currencies) to reduce the current account deficits and the trade account deficits. The trade account can be presented with eq. (1), as following,

$$
T A=X-M=f_{1}\left(p, Y^{*}\right)-f_{2}(p, Y)
$$

where, $Y=$ domestic income, $Y^{*}=$ foreign income, and $p=$ the relative price level (TOT ) or real exchange rate.

The terms of trade (TOT) are:

$$
p=T O T=\frac{P_{M}}{P_{X}}=\frac{S P^{*}}{P}
$$

where, $\mathrm{p}=$ terms of trade or real exchange rate, $P_{M}=$ price of imports, $P_{X}=$ price of exports, $S=$ spot exchange rate (in U.S. terms, i.e., $\$ / €), P=$ domestic price level, and $P^{*}=$ foreign price level.

By presenting the natural logarithm of a variable with its lower-case letter ( $\ln X_{t} \equiv x_{t}$ ), eq. (2) becomes:

$$
p=\text { tot }_{t}=s_{t}+p_{t}^{*}-p_{t}
$$

Thus, from eq. (1), domestic exports $\left(x_{t}\right)$ or foreign imports $\left(m_{t}^{*}\right)$ and domestic imports $\left(m_{t}\right)$ or foreign exports $\left(x_{t}^{*}\right)$ can be written with the following linear functions:

$$
m_{t}^{*} \equiv x_{t}=\alpha_{0}+\alpha_{1}\left(s_{t}+p_{t}^{*}-p_{t}\right)+\alpha_{2} y_{t}^{*}+\varepsilon_{1 t}
$$




$$
x_{t}^{*} \equiv m_{t}=\beta_{0}-\beta_{1}\left(s_{t}+p_{t}^{*}-p_{t}\right)+\beta_{2} y_{t}+\varepsilon_{2 t}
$$

If the Marshall-Lerner condition (price elasticity of supply of exports and demand for imports), eq. (6), holds (elastic domestic and foreign demands for imports), a devaluation of the dollar can improve the trade account. Devaluation increases the price of imports and reduces the price of exports; and due to the law of demand, imports are falling and exports are increasing and the trade account is improved. The Marshall-Lerner condition holds when,

$$
\left|\beta_{1}\right|+\left|\alpha_{1}\right|>1
$$

We will test the J-curve hypothesis by using first a regression analysis and a GARCH-M model for the exchange rate fluctuation by writing eq. (1) as follows:

$$
T A_{t}=\gamma_{0}+\gamma_{1} Y_{t}+\gamma_{2} Y_{t}^{*}+\gamma_{3} T O T_{t}+\varepsilon_{t}
$$

Now, by taking the logarithms of the variables (the lower case letters are the ln of the capital counterpart), we have:

$$
t a_{t}=\delta_{0}+\delta_{1} y_{t}+\delta_{2} y_{t}^{*}+\delta_{3} p_{t}^{*}-\delta_{4} p_{t}+\delta_{5} s_{t}+\varepsilon_{t}
$$

5 The empirical results (regressions) are as following for the logarithm of the U.S. imports $\left(m_{t}\right)$ from Euro-zone,

$$
\begin{gathered}
x_{t}^{*} \equiv m_{t}=-36.109^{\text {***** }}+0.108\left(s_{t}+p_{t}^{*}-p_{t}\right)+4.505^{\text {***** }} y_{t}+0.972^{\text {**** }} m_{t-1} \\
(4.446) \quad(0.077) \\
R^{2}=0.991, S S R=0.084, F=4,923.423, D-W=1.976, N=141
\end{gathered}
$$

and the U.S. exports $\left(x_{t}\right)$ to Euro-zone,

$$
\begin{gathered}
m_{t}^{*} \equiv x_{t}=-12.013+0.059\left(s_{t}+p_{t}^{*}-p_{t}\right)+3.095^{* * *} y_{t}^{*}+0.999^{* * *} x_{t-1} \\
(163.349)(0.077) \\
R^{2}=0.990, S S R=0.030, F=2,906.507, D-W=1.943, N=95
\end{gathered}
$$

The empirical results show that the price elasticity of demand for imports has wrong sign $(+0.108)$ and it is statistically insignificant. The income elasticity is relatively high $(+4.505)$ and statistically significant at $1 \%$ level. The price elasticity of supply of exports is $(+0.059)$ and the European income elasticity for demand for U.S. exports is (+3.095). Thus, the Marshall-Lerner condition, eq. (6), does not hold: $0.108+0.059=0.167<1$ (inelastic demand and supply; then, a depreciation of the U.S. dollar cannot improve the trade account). Only, it can cause an increase in prices (inflation), due to excess supply of money: $\rho_{M 2, C P I}=+0.923, C P I=>M 2\left(F=11.313^{* * *}\right) ; \rho_{m 2, c p i}=+0.989$, $c p i=>m 2\left(F=8.436^{* * *}\right)$, lower-case letters are the ln of capital ones; $\rho_{M B, C P I}=+0.803$, $C P I=>M B\left(F=4.181^{* *}\right) ; \rho_{i_{F F, C P I}}=-0.508, i_{F F}=>C P I\left(F=13.708^{* * *}\right)$. 
Then, we want to model the conditional variance or volatility of the spot exchange rate $\left(s_{t}\right)$. This volatility can show the significant effect of past exchange rates movements on our trade account. We care for the periods of time that the spot rate has caused a positive adjustment on the trade balance.

$$
t a_{t}=\zeta_{0}+\zeta_{1} y_{t}+\zeta_{2} y_{t}^{*}+\zeta_{3} p_{t}^{*}-\zeta_{4} p_{t}+\zeta_{5} s_{t}+\zeta_{6} \sigma_{s t}^{2}+\varepsilon_{t}
$$

or

$$
t a_{t}=\tau_{0}+\tau_{1} y_{t}+\tau_{2} y_{t}^{*}+\tau_{3}\left(s_{t}+p_{t}^{*}-p_{t}\right)+\tau_{4} \sigma_{s t}^{2}+\varepsilon_{t}
$$

A Generalized Autoregressive Conditional Heteroscedasticity (GARCH) ${ }^{6}$ model can be used, here, to model and forecast the conditional variance of the spot exchange rate. The variance of the dependent variable $\left(t a_{t}\right)$ is modeled as a function of exogenous or predetermined macro-variables $\left(X_{t}^{\prime}\right)$ from both countries and of the conditional variance $\left(\sigma_{t}^{2}\right)$ of the $\left(s_{t}\right)$, which are included in the mean eq. (10) and give the GARCH-in-Mean (GARCH-M) model:

$$
t a_{t}=X_{t}^{\prime} \theta+\lambda \sigma_{t}^{2}+\varepsilon_{t}
$$

The exchange rate fluctuation $\left(\sigma_{s t}^{2}\right)$ is related to $\left(t a_{t}\right)$ and it is shown in the GARCH$\mathrm{M}$ specification with the use of a conditional standard deviation, eq. (11) or the log of the conditional variance, eq. (12), in place of the variance in eq. (10), as follows:

$$
\begin{array}{r}
t a_{t}=X_{t}^{\prime} \theta+\lambda \sigma_{t}+\varepsilon_{t} \\
t a_{t}=X_{t}^{\prime} \theta+\lambda \log \left(\sigma_{t}^{2}\right)+\varepsilon_{t}
\end{array}
$$

The GARCH-M (q, p) variance is:

$$
\sigma_{t}^{2}=\omega+\sum_{j=1}^{q} \beta_{j} \sigma_{t-j}^{2}+\sum_{i=1}^{p} \alpha_{i} \varepsilon_{t-i_{j}}^{2}
$$

Eq. (13) can be extended to allow for the inclusion of exogenous or predetermined regressors, $z_{t}$, in the variance equation:

$$
\sigma_{t}^{2}=\omega+\sum_{j=1}^{q} \beta_{j} \sigma_{t-j}^{2}+\sum_{i=1}^{p} \alpha_{i} \varepsilon_{t-i_{j}}^{2}+z_{t}^{\prime} \pi
$$

We can determine the volatility of the exchange rate $\left(\sigma_{t}^{2}\right)$ in eq. (13) if it is statistically significant by using the multivariate GARCH-M model. ${ }^{7}$ We can begin with the simplest GARCH $(1,1)$ specification or a higher order GARCH model, $\operatorname{GARCH}(\mathrm{q}, \mathrm{p})$ to test the significant of its lagged values on $\left(t a_{t}\right)$, where $\mathrm{q}$ is the

\footnotetext{
${ }^{6}$ See, (Bollerslev, 1986).

${ }^{7}$ See, (Engle, Lilien, and Robins, 1987). Also, (Smith, Soresen, and Wickens, 2003).
} 
order of the autoregressive GARCH terms and $\mathrm{p}$ is the order of the moving average ARCH terms, eq. (13).

In addition, a vector autoregression (VAR) model is used based on exports, eq. (4) and imports, eq. (5), plus the volatility of the real exchange rate $\left(\sigma_{t}^{2}\right)$, which give the following VAR system:

$$
\begin{aligned}
& x_{t}=\alpha_{11} x_{t-j}+\beta_{11} m_{t-j}+\gamma_{11} y_{t}+\delta_{11} y_{t}^{*}+\zeta_{11}\left(s_{t-j}+p_{t-j}^{*}-p_{t-j}\right)+\kappa_{11} \sigma_{\tau}^{2}+\varepsilon_{t} \\
& m_{t}=\alpha_{21} x_{t-j}+\beta_{21} m_{t-j}+\gamma_{21} y_{t}+\delta_{21} y_{t}^{*}+\zeta_{21}\left(s_{t-j}+p_{t-j}^{*}-p_{t-j}\right)+\kappa_{21} \sigma_{\tau}^{2}+\varepsilon_{t}
\end{aligned}
$$

The interrelated objective variables $x_{t}$ and $m_{t}$ of the trade account $\left(t a_{t}=x_{t}-\right.$ $m_{t}$ ) are the endogenous variables of the VAR as a function of the lagged values of these two endogenous variables plus the tot $_{t}$ and the two income $\left(y_{t}\right.$ and $\left.y_{t}^{*}\right)$ variables and the exchange rate volatility $\left(\sigma_{t}^{2}\right)$ measured in terms of conditional variance by using the GARCG-M model.

\section{Empirical Results}

The data are monthly and are coming from Economagic.com, Eurostat, and Bloomberg. For the Euro-zone ( $€$ ), the data are from 2004:12 to 2020:12; for Canada (C\$), they are from 1981:03 to 2020:12; for U.K. (£), the data are from 1990:01 to 2018:05; for Switzerland (SF), the data are from 2001:11 to 2021:02; for Japan (¥), they are from 1990:01 to 2021:02; and lastly, for Australia (A\$), the data are from 1986:10 to 2021:02. The variables are U.S. exports to (usxfc) and imports from (usmfc) these foreign countries, trade accounts (ustafc), incomes ( $y_{t}$ and $y_{t}^{*}$ ), exchange rates $\left(\mathrm{s}_{\mathrm{t}}\right)$, price levels $\left(p_{t}\right.$ and $\left.p_{t}^{*}\right)$, terms of trades $\left(\right.$ tot $\left._{\mathrm{t}}\right)$, and the exchange rates volatilities $\left(\sigma_{t}^{2}\right)$.

We start estimating eq. ( $\left.9^{\prime}\right)$ by using the GARCH-M model of eq. (13). The results appeared in Tables 1a and 1b. We see that the sum of the ARCH and GARCH coefficients $(\alpha+\beta)$ are very close to one (1) for Canada, U.K., Japan, and Australia, indicating that volatility shocks are quite persistent for the countries. These results are often observed in high frequency financial data.

Tables $1 \mathrm{a}$ and $1 \mathrm{~b}$ show that incomes $\left(y_{t}, y_{t}^{*}\right)$ and terms of trade $\left(\right.$ tot $\left._{t}\right)$ are having a significant effect on trade accounts (ustafc). The signs are also correct except some for Japan and Australia. ${ }^{8}$ The volatility $\left(\sigma_{t}^{2}\right)$ of the ustafc has significant effects for EU, U.K., Japan, and Australia. Also, the residual (ARCH) and the variance $(\mathrm{GARCH})$ are mostly highly significant at $1 \%$ and $5 \%$ levels for some countries nine (9) months back (t-9). The 1 of the TOT or real exchange rate $\left(\right.$ tot $\left._{t}\right)$, eq. (3) is going up as spot rate $\left(s_{t}\right)$ is increasing (U.S. dollar is depreciated) and the trade account is improved. This happens with Euro-zone, Canada, Switzerland, Japan, and Australia; with U.K. the trade account has a dubious effect on ustauk. The TOTs are very similar for the six countries in question, Graph A1, in Appendix. Then, the long run estimates of the U.S. exports (us $x f c)$ and U.S. imports (usmfc)

${ }^{8}$ When, $y_{t} \uparrow=>t a_{t} \downarrow, y_{t}^{*} \uparrow=>t a_{t} \uparrow$ and tot $_{t} \uparrow=>t a_{t} \uparrow$. 
from foreign countries, eq. (15), by using a VAR model, are presented in Tables $2 \mathrm{a}$ and $2 \mathrm{~b}$. The VAR model is estimated by using lags of terms of trade $\left(t o t_{t-j}\right)$ up to nine lags $(j=0,1,2,3,4,5,6,7,8,9)$. A devaluation of the dollar $\left(\right.$ tot $\left._{t-5}\right)$ increases significantly (at $10 \%$ level) exports to EU after 5 months; there are insignificant positive effect during other lag periods. A depreciation of the dollar $\left(\right.$ tot $\left._{t-3}\right)$ increases significantly (at 10\% level) imports from EU after 3 months, which reveal the J-curve effect, but there are other insignificant negative effects during other periods. A depreciation of the dollar has some significant effect on exports to and imports from Canada. Also, a depreciation of the dollar reduces exports to Canada $\left(\right.$ tot $\left._{\mathrm{t}-2}\right)$ and ( tot $\left._{\mathrm{t}-5}\right)$ significantly. At the same time imports are going up (tot $\left.\mathrm{t}_{-1}\right)$ significantly at $5 \%$ level (J-curve). The depreciation of the dollar reduces exports to U.K. (tot $\left.t_{-1}\right)$ and later is going up ( tot $_{\mathrm{t}-3}$ and tot $\left.\mathrm{t}_{\mathrm{t}-8}\right)$; it has other insignificant effects, too. A depreciation of the dollar has some negative but insignificant effects on imports from U.K. A devaluation of the dollar reduces exports to Switzerland (tot t- $^{-}$ 1) significant at $1 \%$ level and increases in (tot $\left.t_{t-2}\right)$, imports are increasing (tot $t_{t}$ significantly at $1 \%$ level and are falling in (tot $\left.\mathrm{t}_{-8}\right)$, significant at $1 \%$ level ( $\mathrm{J}$ curve).With Japan, exports are increasing in long run (tot $\mathrm{t}_{\mathrm{t}-5}$ ) and imports are increasing ( tot $_{t-5}$ ) significant at $1 \%$ level. Lastly, with Australia, imports are increasing in ( tot $\left._{\mathrm{t}-3}\right)$ (J-curve). Thus, the existence of the J-curve is more or less proved. The variance of the TA $\left(\sigma_{t}^{2}\right)$ has significant effects on exports to EU, U.K., Switzerland, Japan, and Australia. It has only significant effects on imports from Switzerland.

Consequently, the J-curve has been tested by examining the pattern of distributed effects of the tot $_{t}$ (real exchange rate) on exports and imports, which make up the trade account $\left(t a_{t}=x_{t}-m_{t}\right)$. These coefficients of the lag real exchange rate depreciation (tot) show that the depreciation of the dollar leads to deterioration of trade in the short-run and to an improvement in the trade account after some periods, (Tables $2 \mathrm{a}$ and $2 \mathrm{~b}$ ). These tables are giving some mixed results; the devaluation of the dollar improves the trade with a delay for all the countries (J-curve) with Eurozone, U.K., Canada, Switzerland, Japan, and Australia.

Table 1a: Estimation of Eq. (9') with the use of GARCH-M Model, Eq. (13):

Trade Account and Exchange Rate

\begin{tabular}{|c|c|c|c|c|c|c|}
\hline Variables & ustaeu & ustaeu & ustac & ustac & ustauk & ustauk \\
\hline$C$ & $-0.268^{* *}$ & -0.977 & $5.577^{* * *}$ & $4.843^{* * *}$ & $-8.134^{* * *}$ & $-6.914^{* * *}$ \\
\hline & $(0.116)$ & $(0.882)$ & $(0.211)$ & $(0.252)$ & $(1.758)$ & $(0.294)$ \\
\hline$y_{t}$ & $-0.105^{* * *}$ & -0.055 & $-0.794^{* * *}$ & $-0.679^{* * *}$ & $-1.530^{* * *}$ & $-1.512^{* * *}$ \\
\hline & $(0.038)$ & $(0.099)$ & $(0.032)$ & $(0.038)$ & $(0.337)$ & $(0.048)$ \\
\hline$y_{t}^{*}$ & $0.132^{* * *}$ & $0.129^{* * *}$ & $0.265^{* * *}$ & $0.202^{* * *}$ & $1.770^{* * *}$ & $1.705^{* * *}$ \\
\hline & $(0.036)$ & $(0.024)$ & $(0.015)$ & $(0.017)$ & $(0.380)$ & $(0.018)$ \\
\hline tot $_{t}$ & $0.347^{* * *}$ & $0.282^{* * *}$ & $0.248^{* * *}$ & $0.124^{* * *}$ & $0.219^{* *}$ & $-0.131^{* *}$ \\
\hline & $(0.004)$ & $(0.042)$ & $(0.022)$ & $(0.028)$ & $(0.101)$ & $(0.061)$ \\
\hline
\end{tabular}




\begin{tabular}{|c|c|c|c|c|c|c|}
\hline$\sigma_{\tau}^{2}$ & - & $2.871^{* * *}$ & - & - & - & $-4.309^{* * * *}$ \\
\hline & - & $(0.581)$ & - & - & - & $\begin{array}{l}(0.811) \\
\end{array}$ \\
\hline \multicolumn{7}{|c|}{ Variance Equation } \\
\hline \multirow[t]{2}{*}{$C$} & $0.007^{* * *}$ & $0.011^{* * *}$ & 0.001 & 0.003 & $0.010^{*}$ & $0.019^{* * *}$ \\
\hline & $(0.001)$ & $(0.004)$ & $(0.001)$ & $(0.006)$ & $(0.006)$ & $(0.004)$ \\
\hline \multirow{2}{*}{$\varepsilon_{t-1}^{2}$} & $0.121^{* *}$ & $-0.055^{*}$ & $0.494^{* * *}$ & $0.353^{* * *}$ & $0.365^{* * *}$ & $0.110^{* * * *}$ \\
\hline & $(0.054)$ & $(0.033)$ & $(0.129)$ & $(0.116)$ & $(0.116)$ & $(0.025)$ \\
\hline \multirow[t]{2}{*}{$\varepsilon_{t-2}^{2}$} & 0.081 & $0.147^{* *}$ & $-0.352^{* *}$ & 0.104 & 0.143 & $0.101^{* * *}$ \\
\hline & $(0.063)$ & $(0.064)$ & $(0.156)$ & $(0.941)$ & $(0.143)$ & $(0.022)$ \\
\hline \multirow[t]{2}{*}{$\varepsilon_{t-3}^{2}$} & - & -0.001 & - & 0.056 & - & 0.038 \\
\hline & - & $(0.110)$ & - & $(0.663)$ & - & $(0.030)$ \\
\hline \multirow[t]{2}{*}{$\varepsilon_{t-4}^{2}$} & - & 0.008 & - & 0.076 & - & -0.003 \\
\hline & - & $(0.070)$ & - & $(0.533)$ & - & $(0.020)$ \\
\hline \multirow[t]{2}{*}{$\varepsilon_{t-5}^{2}$} & - & -0.048 & - & 0.105 & - & $0.069^{* *}$ \\
\hline & - & $(0.061)$ & - & $(0.341)$ & - & $(0.029)$ \\
\hline \multirow[t]{2}{*}{$\varepsilon_{t-6}^{2}$} & - & 0.014 & - & 0.108 & - & $0.058^{* * *}$ \\
\hline & - & $(0.047)$ & & $(0.157)$ & & $(0.019)$ \\
\hline \multirow[t]{2}{*}{$\varepsilon_{\tau-7}^{2}$} & - & $0.141^{*}$ & - & 0.075 & - & 0.024 \\
\hline & - & $(0.076)$ & - & $(0.325)$ & - & $(0.028)$ \\
\hline \multirow[t]{2}{*}{$\varepsilon_{\tau-8}^{2}$} & - & 0.196 & - & -0.034 & - & $0.045^{* *}$ \\
\hline & - & $(0.141)$ & - & $(0.310)$ & - & $(0.023)$ \\
\hline \multirow[t]{2}{*}{$\varepsilon_{\tau-9}^{2}$} & & -0.022 & & 0.093 & & $0.143^{* * *}$ \\
\hline & & $(0.064)$ & & $(0.298)$ & & $(0.035)$ \\
\hline \multirow[t]{2}{*}{$\sigma_{t-1}^{2}$} & $0.695^{* * *}$ & 0.261 & $0.806^{* * *}$ & 0.060 & -0.302 & 0.041 \\
\hline & $(0.094)$ & $(0.509)$ & $(0.281)$ & $(2.636)$ & $(0.219)$ & $(0.139)$ \\
\hline \multirow[t]{2}{*}{$\sigma_{t-2}^{2}$} & $-0.872^{* * *}$ & -0.646 & 0.019 & -0.085 & $0.455^{* * *}$ & $0.372^{* *}$ \\
\hline & $(0.075)$ & $(0.431)$ & $(0.189)$ & (1.456) & $(0.145)$ & $(0.151)$ \\
\hline \multirow[t]{2}{*}{$\sigma_{t-3}^{2}$} & - & 0.029 & - & -0.079 & - & 0.117 \\
\hline & - & $(0.518)$ & - & $(1.242)$ & - & $(0.148)$ \\
\hline \multirow[t]{2}{*}{$\overline{\sigma_{t-4}^{2}}$} & - & -0.105 & - & -0.084 & - & $-0.662^{* * * *}$ \\
\hline & - & $(0.392)$ & - & $(0.787)$ & - & $(0.158)$ \\
\hline \multirow[t]{2}{*}{$\sigma_{t-5}^{2}$} & - & -0.394 & - & -0.055 & - & -0.001 \\
\hline & - & $(0.329)$ & - & $(0.552)$ & & $(0.198)$ \\
\hline \multirow[t]{2}{*}{$\sigma_{t-6}^{2}$} & - & -0.116 & - & -0.048 & - & $-0.282^{*}$ \\
\hline & & $(0.493)$ & & $(0.621)$ & & $(0.169)$ \\
\hline \multirow[t]{2}{*}{$\sigma_{\tau-7}^{2}$} & & -0.230 & & -0.054 & & -0.002 \\
\hline & & $(0.298)$ & & $(0.525)$ & & $(0.131)$ \\
\hline$\sigma_{\tau-8}^{2}$ & & -0.313 & & -0.026 & & -0.212 \\
\hline
\end{tabular}




\begin{tabular}{|c|c|c|c|c|c|c|}
\hline & & $(0.333)$ & & $(0.477)$ & & $(0.144)$ \\
\hline$\sigma_{\tau-9}^{2}$ & & $-0.159^{*}$ & & -0.022 & & 0.091 \\
\hline$R^{2}$ & 0.403 & 0.494 & 0.537 & 0.564 & 0.053 & 0.357 \\
\hline$S E R$ & 0.081 & 0.079 & 0.085 & 0.084 & 0.181 & 0.154 \\
\hline$D-W$ & 1.148 & 1.157 & 0.578 & 0.602 & 0.629 & 0.901 \\
\hline$F$ & & 7.166 & 67.951 & 26.703 & & 7.663 \\
\hline$N$ & 193 & 193 & 478 & 478 & 341 & 341 \\
\hline$R M S E$ & 0.079895 & 0.080150 & 0.084509 & 0.082037 & 0.179635 & 0.188714 \\
\hline
\end{tabular}

Note: ustaeu $=\ln$ of U.S. Trade Account with EU, ustac $=\ln$ of U.S. Trade Account with Canada, ustauk $=\ln$ of U.S. Trade Account with U.K., $y_{t}=\ln$ of U.S. Income (GDP), $y_{t}^{*}=\ln$ of foreign Income (GDP), $t o t_{t}=\ln$ of Terms of Trade (Real Exchange Rate), $\varepsilon_{t-j}^{2}=$ lag of Residual $(\mathrm{ARCH}), \sigma_{t-j}^{2} \quad=$ lag of Variance $(\mathrm{GARCH}), R^{2}=\mathrm{R}$-squared, $S E R=$ S.E. of regression, $D-W=$ Durbin-Watson statistic, $F=\mathrm{F}$ statistic, $N=$ number of observations, $R M S E=$ Root Mean Squared Error, *** significant at the 1\% level, ** significant at the 5\% level, and $*$ significant at the $10 \%$ level. Source: Economagic.com, Bloomberg, and Eurostat.

Table 1b: Estimation of Eq. (9') with the use of GARCH-M Model, Eq. (13): Trade Account and Exchange Rate

\begin{tabular}{|c|c|c|c|c|c|c|}
\hline Variables & ustaeu & ustaeu & ustac & ustac & ustauk & ustauk \\
\hline \multirow[t]{2}{*}{$C$} & $20.639^{* * *}$ & $-3.802^{*}$ & $3.689^{* * *}$ & $2.891^{* *}$ & $-1.758^{* * *}$ & -1.389 \\
\hline & $(0.341)$ & $(1.947)$ & $(1.789)$ & (1.313) & $(0.553)$ & $(1.277)$ \\
\hline \multirow[t]{2}{*}{$y_{t}$} & $-3.426^{* * * *}$ & 0.064 & $0.043^{* *}$ & 0.090 & $0.852^{* * * *}$ & $0.982^{* * *}$ \\
\hline & $(0.025)$ & $(0.228)$ & $(0.021)$ & $(0.063)$ & $(0.133)$ & $(0.324)$ \\
\hline \multirow[t]{2}{*}{$y_{t}^{*}$} & $1.422^{* * *}$ & $0.624^{* * *}$ & $-0.341^{* *}$ & $-0.333^{* * *}$ & $-0.384^{* * *}$ & $-0.515^{\text {*** }}$ \\
\hline & $(0.047)$ & $(0.159)$ & $(0.151)$ & $(0.110)$ & $(0.061)$ & $(0.145)$ \\
\hline \multirow[t]{2}{*}{ tot $_{t}$} & $0.649^{* * *}$ & $0.401^{* * * *}$ & $0.046^{* *}$ & $0.095^{*}$ & $0.704^{* * * *}$ & $0.738^{* * * *}$ \\
\hline & $(0.086)$ & $(0.195)$ & $(0.022)$ & $(0.052)$ & $(0.051)$ & $(0.078)$ \\
\hline \multirow[t]{2}{*}{$\overline{\sigma_{\tau}^{2}}$} & - & & - & $5.545^{* * *}$ & - & $0.407^{* *}$ \\
\hline & - & & - & $(0.940)$ & - & $(0.192)$ \\
\hline \multicolumn{7}{|c|}{ Variance Equation } \\
\hline \multirow[t]{2}{*}{$C$} & $0.021^{*}$ & 0.008 & 0.005 & $0.002^{* *}$ & $0.005^{* * *}$ & 0.020 \\
\hline & $(0.013)$ & $(0.010)$ & $(0.003)$ & $(0.001)$ & $(0.002)$ & $(0.032)$ \\
\hline \multirow[t]{2}{*}{$\varepsilon_{t-1}^{2}$} & $0.585^{* * *}$ & 0.115 & $0.405^{* * *}$ & $0.138^{* * *}$ & $0.286^{* * *}$ & $0.243^{* *}$ \\
\hline & $(0.138)$ & $(0.105)$ & $(0.122)$ & $(0.026)$ & $(0.076)$ & $(0.102)$ \\
\hline \multirow[t]{2}{*}{$\varepsilon_{t-2}^{2}$} & 0.327 & -0.107 & -0.043 & $0.083^{* * *}$ & $-0.171^{* * * *}$ & 0.042 \\
\hline & $(0.350)$ & $(0.180)$ & $(0.300)$ & $(0.029)$ & $(0.055)$ & $(0.472)$ \\
\hline \multirow[t]{2}{*}{$\varepsilon_{t-3}^{2}$} & - & -0.061 & & 0.007 & $0.281^{* * *}$ & 0.116 \\
\hline & & $(0.275)$ & & $(0.018)$ & $(0.050)$ & $(0.574)$ \\
\hline$\varepsilon_{t-4}^{2}$ & - & 0.024 & & $0.106^{* * *}$ & - & 0.140 \\
\hline
\end{tabular}




\begin{tabular}{|c|c|c|c|c|c|c|}
\hline & & $(0.215)$ & & $(0.020)$ & & $(0.239)$ \\
\hline \multirow[t]{2}{*}{$\varepsilon_{t-5}^{2}$} & - & 0.082 & & $0.098^{* * *}$ & & 0.105 \\
\hline & & $(0.217)$ & & $(0.025)$ & & $(0.338)$ \\
\hline \multirow[t]{2}{*}{$\varepsilon_{t-6}^{2}$} & - & -0.104 & & -0.006 & & -0.003 \\
\hline & & $(0.293)$ & & $(0.025)$ & & $(0.329)$ \\
\hline \multirow[t]{2}{*}{$\varepsilon_{\tau-7}^{2}$} & - & -0.013 & - & 0.020 & & 0.169 \\
\hline & & $(0.355)$ & & $(0.014)$ & & $(0.179)$ \\
\hline \multirow[t]{2}{*}{$\varepsilon_{\tau-8}^{2}$} & & 0.071 & & 0.016 & & 0.063 \\
\hline & & $(0.316)$ & & $(0.013)$ & & $(0.412)$ \\
\hline \multirow[t]{2}{*}{$\varepsilon_{\tau-9}^{2}$} & & -0.113 & & $-0.076^{* * * *}$ & & 0.064 \\
\hline & & $(0.146)$ & & $(0.022)$ & & $(0.464)$ \\
\hline \multirow[t]{2}{*}{$\sigma_{t-1}^{2}$} & -0.703 & 0.197 & 0.492 & -0.101 & $0.695^{* * * *}$ & -0.040 \\
\hline & $(0.581)$ & (1.490) & $(0.560)$ & $(0.137)$ & $(0.103)$ & (1.959) \\
\hline \multirow[t]{2}{*}{$\sigma_{t-2}^{2}$} & 0.067 & -0.016 & -0.183 & $0.485^{* * *}$ & $-0.758^{* * *}$ & -0.056 \\
\hline & $(0.249)$ & $(1.505)$ & $(0.122)$ & $(0.091)$ & $(0.066)$ & $(2.443)$ \\
\hline \multirow[t]{2}{*}{$\sigma_{t-3}^{2}$} & & 0.040 & & $-0.439^{* * *}$ & $0.550^{* * * *}$ & -0.005 \\
\hline & & (1.177) & & $(0.117)$ & $(0.048)$ & $(1.088)$ \\
\hline \multirow[t]{2}{*}{$\sigma_{t-4}^{2}$} & & 0.086 & & $-0.865^{* * * *}$ & & -0.015 \\
\hline & & $(1.355)$ & & $(0.122)$ & & $(0.579)$ \\
\hline \multirow[t]{2}{*}{$\sigma_{t-5}^{2}$} & & -0.016 & & $0.696^{\text {**** }}$ & & -0.074 \\
\hline & & $(1.185)$ & & $(0.140)$ & & $(0.648)$ \\
\hline \multirow[t]{2}{*}{$\sigma_{t-6}^{2}$} & & 0.009 & & $0.358^{* * *}$ & & -0.036 \\
\hline & & $(1.071)$ & & $(0.117)$ & & $(0.360)$ \\
\hline \multirow[t]{2}{*}{$\sigma_{\tau-7}^{2}$} & & 0.042 & & -0.167 & & -0.021 \\
\hline & & $(0.855)$ & & $(0.117)$ & & $(0.375)$ \\
\hline \multirow[t]{2}{*}{$\sigma_{\tau-8}^{2}$} & & 0.090 & & $0.164^{*}$ & & -0.075 \\
\hline & & $(0.892)$ & & $(0.092)$ & & $(0.367)$ \\
\hline \multirow[t]{2}{*}{$\sigma_{\tau-9}^{2}$} & & -0.049 & & $0.224^{* * *}$ & & -0.104 \\
\hline & & $(0.737)$ & & $(0.071)$ & & $(0.315)$ \\
\hline$R^{2}$ & 0.503 & 0.594 & 0.006 & 0.494 & 0.024 & 0.173 \\
\hline SER & 0.221 & 0.115 & 0.123 & 0.089 & 0.237 & 0.224 \\
\hline$D-W$ & 0.524 & 1.394 & 0.600 & 1.474 & 0.654 & 0.781 \\
\hline$F$ & - & 7.918 & - & 13.253 & & 3.548 \\
\hline$N$ & 232 & 142 & 374 & 336 & 413 & 413 \\
\hline$R M S E$ & 0.219007 & 0.105091 & 0.122418 & 0.122733 & 0.236287 & 0.222028 \\
\hline
\end{tabular}

Note: See, Table 1a. ustasw $=\ln$ of U.S. Trade Account with Switzerland, ustaj $=\ln$ of U.S.

Trade Account with Japan, ustaa $=\ln$ of U.S. Trade Account with Australia.

Source: See, Table 1a. 
Table 2a: VAR Estimates of Eq. (15): Effects of Terms of Trade on Exports and Imports

\begin{tabular}{|c|c|c|c|c|c|c|}
\hline Variables & usxeu & usmeu & usxc & usmc & usxuk & usmuk \\
\hline \multirow[t]{2}{*}{$u s x f c_{t-1}$} & $0.371^{* * * *}$ & 0.048 & $0.468^{* * * *}$ & -0.025 & $0.566^{* * * *}$ & 0.067 \\
\hline & $(0.085)$ & $(0.103)$ & $(0.075)$ & $(0.065)$ & $(0.055)$ & $(0.060)$ \\
\hline \multirow[t]{2}{*}{$u s x f c_{t-2}$} & 0.095 & 0.046 & 0.064 & $-0.158^{* * * *}$ & $0.196^{* * *}$ & -0.023 \\
\hline & $(0.080)$ & $(0.096)$ & $(0.075)$ & $(0.065)$ & $(0.055)$ & $(0.060)$ \\
\hline \multirow[t]{2}{*}{$u s m f c_{t-1}$} & $-0.165^{* * *}$ & $0.296^{* * * *}$ & $0.172^{* *}$ & $0.608^{* * *}$ & 0.044 & $0.492^{* * *}$ \\
\hline & $(0.070)$ & $(0.085)$ & $(0.086)$ & $(0.074)$ & $(0.050)$ & $(0.055)$ \\
\hline \multirow[t]{2}{*}{$u s m f c_{t-2}$} & -0.024 & 0.026 & -0.068 & $0.289^{* * *}$ & $-0.104^{* * *}$ & $0.219^{* * *}$ \\
\hline & $(0.071)$ & $(0.085)$ & $(0.085)$ & $(0.074)$ & $(0.050)$ & $(0.054)$ \\
\hline \multirow[t]{2}{*}{$C$} & $-14.293^{* * *}$ & $-11.770^{* * *}$ & $-2.993^{* * *}$ & $-3.191 * * *$ & $8.476^{* * *}$ & 1.602 \\
\hline & (1.991) & $(2.397)$ & $(0.656)$ & $(0.567)$ & $(3.703)$ & $(4.031)$ \\
\hline \multirow[t]{2}{*}{$y_{t}$} & $2.360^{* * *}$ & $1.859^{* * *}$ & $0.725^{* * *}$ & $0.687^{* * *}$ & $2.205^{* * *}$ & 0.725 \\
\hline & $(0.275)$ & $(0.331)$ & $(0.124)$ & $(0.107)$ & $(0.759)$ & $(0.826)$ \\
\hline \multirow[t]{2}{*}{$y_{t}^{*}$} & $-0.129^{*}$ & -0.034 & $-0.054^{* *}$ & $-0.079^{* * *}$ & $-2.106^{* * * *}$ & -0.507 \\
\hline & $(0.086)$ & $(0.103)$ & $(0.027)$ & $(0.023)$ & $(0.843)$ & $(0.918)$ \\
\hline \multirow[t]{2}{*}{$t^{\prime} t_{t}$} & 0.002 & 0.297 & -0.182 & -0.210 & $0.499^{* * * *}$ & -0.306 \\
\hline & $(0.238)$ & $(0.286)$ & $(0.210)$ & $(0.182)$ & $(0.224)$ & $(0.241)$ \\
\hline \multirow[t]{2}{*}{$t t_{t-1}$} & -0.141 & -0.361 & $0.555^{*}$ & $0.545^{* *}$ & $-0.706^{* * * *}$ & 0.140 \\
\hline & $(0.247)$ & $(0.297)$ & $(0.308)$ & $(0.266)$ & $(0.333)$ & $(0.362)$ \\
\hline \multirow[t]{2}{*}{ tot $_{t-2}$} & 0.177 & -0.028 & $-0.584^{* *}$ & -0.338 & -0.301 & -0.036 \\
\hline & $(0.247)$ & $(0.298)$ & $(0.310)$ & $(0.267)$ & $(0.335)$ & $(0.364)$ \\
\hline \multirow[t]{2}{*}{$t_{t o t_{t-3}}$} & 0.037 & $0.483^{*}$ & 0.128 & 0.092 & $1.012^{* * *}$ & 0.082 \\
\hline & $(0.244)$ & $(0.294)$ & $(0.309)$ & $(0.267)$ & $(0.333)$ & $(0.362)$ \\
\hline \multirow[t]{2}{*}{$\operatorname{tot}_{t-4}$} & -0.246 & -0.307 & 0.319 & 0.177 & -0.393 & 0.151 \\
\hline & $(0.246)$ & $(0.295)$ & $(0.308)$ & $(0.266)$ & $(0.337)$ & $(0.367)$ \\
\hline \multirow[t]{2}{*}{$\operatorname{tot}_{t-5}$} & $0.377^{*}$ & -0.098 & $-0.465^{*}$ & -0.309 & 0.095 & -0.110 \\
\hline & $(0.245)$ & $(0.295)$ & $(0.308)$ & $(0.266)$ & $(0.334)$ & $(0.363)$ \\
\hline \multirow[t]{2}{*}{$\operatorname{tot}_{t-6}$} & 0.050 & 0.404 & 0.224 & 0.023 & 0.310 & 0.161 \\
\hline & $(0.250)$ & $(0.301)$ & $(0.309)$ & $(0.267)$ & $(0.331)$ & $(0.360)$ \\
\hline \multirow[t]{2}{*}{ tot $_{t-7}$} & 0.113 & 0.225 & 0.028 & 0.043 & $-0.844^{* * *}$ & -0.135 \\
\hline & $(0.251)$ & $(0.302)$ & $(0.309)$ & $(0.266)$ & $(0.328)$ & $(0.357)$ \\
\hline \multirow[t]{2}{*}{ tot $_{t-8}$} & -0.036 & -0.376 & -0.116 & 0.008 & $0.494^{*}$ & 0.010 \\
\hline & $(0.248)$ & $(0.299)$ & $(0.308)$ & $(0.266)$ & $(0.328)$ & $(0.357)$ \\
\hline \multirow[t]{2}{*}{$t_{0} t_{t-9}$} & 0.040 & 0.029 & 0.183 & 0.003 & -0.132 & -0.033 \\
\hline & $(0.178)$ & $(0.214)$ & $(0.211)$ & $(0.182)$ & $(0.212)$ & $(0.231)$ \\
\hline \multirow[t]{2}{*}{$\sigma_{t}^{2}$} & $0.918^{*}$ & -0.150 & - & - & $1.095^{* * *}$ & -0.095 \\
\hline & $(0.595)$ & $(0.716)$ & & & $(0.477)$ & $(0.519)$ \\
\hline$R^{2}$ & 0.860 & 0.873 & 0.972 & 0.985 & 0.903 & 0.882 \\
\hline
\end{tabular}




\begin{tabular}{|c|c|c|c|c|c|c|}
\hline$S E E$ & 0.061 & 0.073 & 0.093 & 0.080 & 0.092 & 0.100 \\
\hline$F$ & 62.571 & 69.793 & 1007.942 & 1832.216 & 176.613 & 142.216 \\
\hline$N$ & 191 & 191 & 478 & 478 & 341 & 341 \\
\hline
\end{tabular}

Note: See, Table 1a. usxeu = ln of U.S. exports to EU, usmeu = ln of U.S. imports from EU, $u s x f c=\ln$ of U.S. exports to foreign country, $u s m f c=\ln$ of U.S. imports from foreign country, $S E E=$ S.E. of equation.

Source: See, Table 1a.

Table 2b: VAR Estimates of Eq. (15): Effects of Terms of Trade on Exports and Imports

\begin{tabular}{|c|c|c|c|c|c|c|}
\hline Variables & $u s x s w$ & usmsw & $u s x j$ & $u s m j$ & usxa & usma \\
\hline \multirow[t]{2}{*}{$u s x f c_{t-1}$} & $0.489^{* * *}$ & $-0.735^{*}$ & $0.343^{* * * *}$ & -0.021 & $0.344^{* * *}$ & 0.084 \\
\hline & $(0.103)$ & $(0.403)$ & $(0.057)$ & $(0.064)$ & $(0.050)$ & $(0.065)$ \\
\hline \multirow[t]{2}{*}{$u s x f c_{t-2}$} & -0.103 & $0.758^{* *}$ & $0.405^{* * *}$ & -0.058 & $0.229^{* * * *}$ & $-0.176^{* * * *}$ \\
\hline & $(0.093)$ & $(0.363)$ & $(0.057)$ & $(0.064)$ & $(0.049)$ & $(0.064)$ \\
\hline \multirow[t]{2}{*}{$u s m f c_{t-1}$} & -0.023 & 0.028 & 0.053 & $0.569^{* * * *}$ & $-0.142^{* * * *}$ & $0.438 * * *$ \\
\hline & $(0.026)$ & $(0.103)$ & $(0.055)$ & $(0.062)$ & $(0.038)$ & $(0.050)$ \\
\hline \multirow[t]{2}{*}{$u s m f c_{t-2}$} & 0.028 & $-0.197^{* *}$ & -0.068 & $0.171^{* * * *}$ & 0.056 & $0.186^{* * * *}$ \\
\hline & $(0.026)$ & $(0.100)$ & $(0.055)$ & $(0.062)$ & $(0.039)$ & $(0.051)$ \\
\hline \multirow[t]{2}{*}{$C$} & $-19.326^{* * * *}$ & $-16.420^{* * *}$ & $-11.147^{* * * *}$ & -1.311 & $-156.167^{* * *}$ & 1.192 \\
\hline & $(2.861)$ & $(11.173)$ & $(4.303)$ & $(4.860)$ & $(66.083)$ & $(86.525)$ \\
\hline \multirow[t]{2}{*}{$y_{t}$} & $1.319^{* * * *}$ & $2.697^{* * *}$ & -0.028 & $0.142^{*}$ & $115.661^{* * * *}$ & -7.449 \\
\hline & $(0.212)$ & $(0.826)$ & $(0.077)$ & $(0.087)$ & $(49.727)$ & $(65.109)$ \\
\hline \multirow[t]{2}{*}{$y_{t}^{*}$} & $1.326^{* * *}$ & $2.295^{* * * *}$ & $1.164^{* * * *}$ & 0.283 & $-60.247^{* * * *}$ & 4.285 \\
\hline & $(0.227)$ & $(0.887)$ & $(0.400)$ & $(0.452)$ & $(26.062)$ & $(34.124)$ \\
\hline \multirow[t]{2}{*}{ tot $_{t}$} & $1.059^{* * *}$ & $0.969^{* * * *}$ & $0.326^{*}$ & 0.221 & $86.815^{\text {*** }}$ & -6.155 \\
\hline & $(0.114)$ & $(0.444)$ & $(0.189)$ & $(0.214)$ & $(37.344)$ & (48.896) \\
\hline \multirow[t]{2}{*}{$\operatorname{tot}_{t-1}$} & $-0.437^{* * *}$ & 0.476 & -0.393 & -0.152 & -0.486 & 0.157 \\
\hline & $(0.188)$ & $(0.733)$ & $(0.268)$ & $(0.302)$ & $(0.366)$ & $(0.479)$ \\
\hline \multirow[t]{2}{*}{$t^{t o t_{t-2}}$} & $0.298^{*}$ & -0.535 & -0.318 & 0.133 & -0.197 & -0.761 \\
\hline & $(0.179)$ & $(0.699)$ & $(0.268)$ & $(0.302)$ & $(0.379)$ & $(0.496)$ \\
\hline \multirow[t]{2}{*}{$t^{t o t_{t-3}}$} & 0.018 & 0.524 & 0.134 & $-0.483^{*}$ & 0.249 & $0.899^{*}$ \\
\hline & $(0.159)$ & $(0.621)$ & $(0.264)$ & $(0.298)$ & $(0.382)$ & $(0.499)$ \\
\hline \multirow[t]{2}{*}{$\operatorname{tot}_{t-4}$} & 0.145 & 0.162 & -0.239 & -0.101 & -0.001 & -0.182 \\
\hline & $(0.156)$ & $(0.609)$ & $(0.264)$ & $(0.299)$ & $(0.383)$ & $(0.501)$ \\
\hline \multirow[t]{2}{*}{$t_{t o t_{t-5}}$} & 0.028 & 0.481 & $0.579^{* * *}$ & $0.798^{* * *}$ & 0.379 & 0.077 \\
\hline & $(0.154)$ & $(0.603)$ & $(0.263)$ & $(0.297)$ & $(0.382)$ & $(0.499)$ \\
\hline \multirow[t]{2}{*}{$t_{0} t_{t-6}$} & -0.107 & 0.710 & -0.229 & -0.284 & -0.419 & 0.035 \\
\hline & $(0.157)$ & $(0.615)$ & $(0.266)$ & $(0.301)$ & $(0.381)$ & $(0.499)$ \\
\hline \multirow[t]{2}{*}{$t_{o t} t_{t-7}$} & -0.218 & -0.691 & -0.121 & -0.361 & -0.004 & 0.003 \\
\hline & $(0.163)$ & $(0.637)$ & $(0.264)$ & $(0.298)$ & $(0.379)$ & $(0.497)$ \\
\hline \multirow[t]{2}{*}{$t^{\prime} t_{t-8}$} & 0.109 & $-1.360^{* * * *}$ & -0.018 & 0.009 & 0.190 & 0.270 \\
\hline & $(0.159)$ & $(0.620)$ & $(0.261)$ & $(0.295)$ & $(0.365)$ & $(0.478)$ \\
\hline \multirow[t]{2}{*}{$\operatorname{tot}_{t-9}$} & -0.151 & $0.777^{* *}$ & 0.236 & $0.320^{*}$ & -0.026 & -0.307 \\
\hline & $(0.109)$ & $(0.426)$ & $(0.165)$ & $(0.187)$ & $(0.224)$ & $(0.293)$ \\
\hline
\end{tabular}




\begin{tabular}{|c|c|c|c|c|c|c|}
\hline$\sigma_{t}^{2}$ & $-0.402^{* * *}$ & $-1.822^{* * *}$ & $2.626^{* * *}$ & 0.192 & $-116.726^{* * *}$ & 8.306 \\
\hline$R^{2}$ & $(0.173)$ & $(0.675)$ & $(1.015)$ & $(1.146)$ & $(50.626)$ & $(66.287)$ \\
\hline$S E E$ & 0.995 & 0.878 & 0.726 & 0.703 & 0.926 & 0.891 \\
\hline$F$ & 0.022 & 0.086 & 0.072 & 0.081 & 0.111 & 0.145 \\
\hline$N$ & 967.728 & 34.368 & 48.225 & 42.965 & 282.120 & 185.490 \\
\hline
\end{tabular}

Note: See, Tables 1a and 2a. usxsw $=\ln$ of U.S. exports to Switzerland, usmsw $=\ln$ of U.S. imports from Switzerland, $u s x j=\ln$ of U.S. exports to Japan, , usmj $=\ln$ of U.S. imports from Japan, usxa $=\ln$ of U.S. exports to Australia, usma $=\ln$ of U.S. imports from Australia. Source: See, Table 1a. 


\section{Policy Implications}

The J-curve hypothesis says that after the depreciation of a currency (\$) or increase of the spot exchange rate $S_{t}(\$ / €)$, the balance of trade worsens in the short-run, but improves in the long-run, (Figure 1). The trade balance $(T A=0)$ is very important for a country and shows its competitiveness, production, employment, ${ }^{9}$ resources, self-sufficiency, autarky, public policy effectiveness, etc. The U.S. trade deficit after 1980 is enormous, ${ }^{10}$ showing and proving the inefficiency of the public policies and the aggravation of the structural problems of our economy.

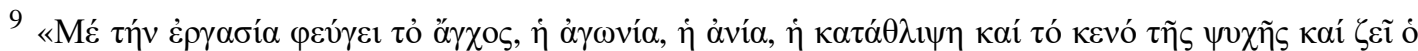

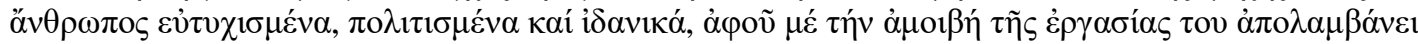

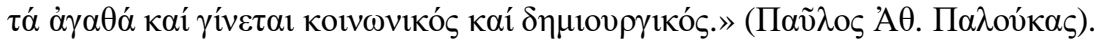

10 The trade deficit for the $3^{\text {rd }}$ quarter of 2021 was $\$ 274.8$ billion and the current account deficit was $\$ 214.8$ billion, or $3.7 \%$ of the GDP. The U.S. current account the last 60 years is as follows (Graph 2):

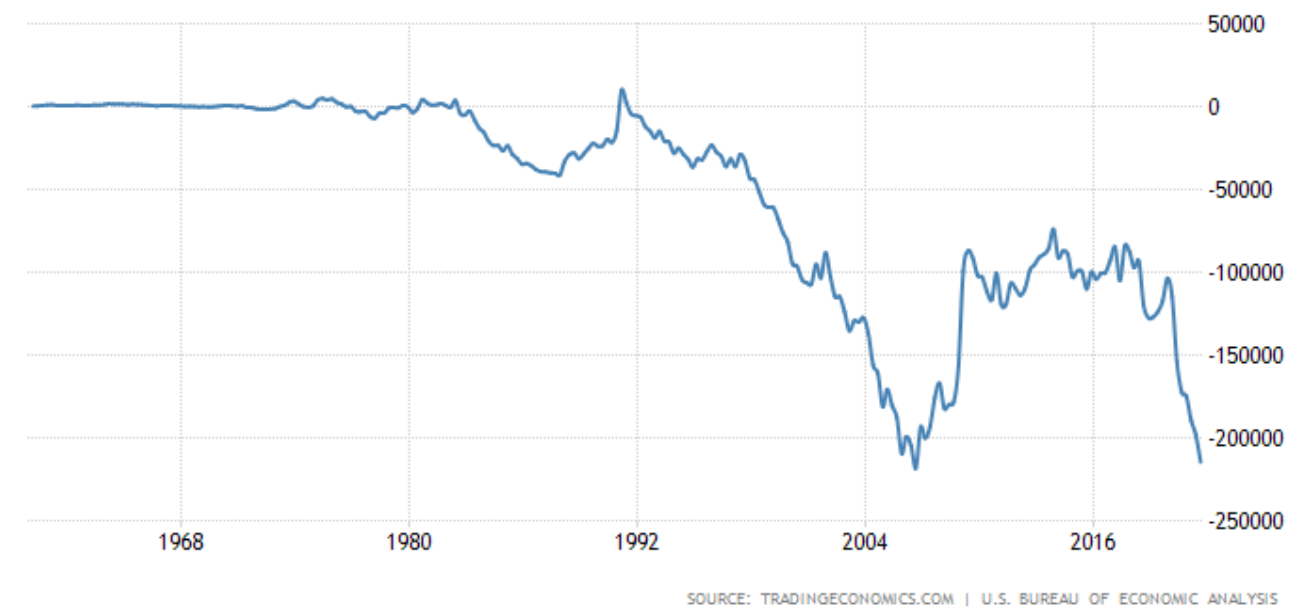

Graph 2: U.S. Current Account (1960-2021)

Note: The current account was in balance until late 1970s and had the highest deficit during the years 2005-2008. The current account gap in the US widened to $\$ 214.8$ billion or $3.7 \%$ of the GDP in the third quarter of 2021 from an upwardly revised $\$ 198.3$ billion in the prior period and compared to forecasts of a \$205 billion shortfall. It was the largest current account deficit since Q3 2006 as imports surged to a record as companies were trying to fill up inventories. Reduced surplus on services and expanded deficits on secondary income and on goods were partly offset by an expanded surplus on primary income. The services surplus shrank to $\$ 49.9$ billion from $\$ 62.6$ billion in Q2, the goods deficit rose to $\$ 274.8$ billion from $\$ 269.6$ billion, led by imports of industrial supplies and materials, mainly petroleum and products and metals and nonmetallic products. The secondary income shortfall advanced to $\$ 38$ billion from $\$ 30$ billion.

source: U.S. Bureau of Economic Analysis

and https://tradingeconomics.com/united-states/current-account 
Two important events that have contributed to deterioration of the U.S. trade account were: First, the NAFTA agreement in 1994, signed by President Clinton. ${ }^{11}$ And second, the entrance of China to the World Trade Organization (WTO) on October 11, 2001. ${ }^{12}$

11 "NAFTA is over 1,700 pages long: 741 pages for the treaty itself, 348 pages for annexes, and 619 pages for footnotes and explanations. It is difficult to see how 1,700 pages of government rules and regulations can free trade. By definition, free trade is the removal of government from the trading process, not its expansion." See, Joe Ogrinc, “The NAFTA Analysis: Not Free Trade”, It is difficult to see how 1,700 pages of government rules and regulations can free trade, Saturday, May 1, 1993. https://fee.org/articles/the-nafta-analysis-not-free trade/?gclid=EAIaIQobChMItPzezpCC9QIVArjICh1dPwHqEAAYAiAAEgJEsfD_BwE.

On September 30, 2018, an agreement was reached during re-negotiations on changes to NAFTA. The next day, a re-negotiated version of the agreement was published, and referred to as the United States-Mexico-Canada Agreement (USMCA). In November of 2018, at the G20 summit, the USMCA was signed by President Trump, Canadian Prime Minister Justin Trudeau and thenMexican President Enrique Peña Nieto. See, Anne Sraders, "What Is NAFTA? History, Purpose and What It Means in 2019". https://www.thestreet.com/politics/nafta-north-american-free-tradeagreement-14651970. "Since NAFTA was ratified, U.S.-Mexico trade-excluding services and petroleum, which are not addressed by NAFTA-has grown three and a half times faster than U.S. GDP. The United States ran a small trade surplus with Mexico in 1993; today, the U.S.-Mexico trade deficit is America's second largest. If NAFTA were solely responsible for all that trade, it might appear that renegotiating it to obtain more favorable terms for the United States would have big payoffs, and that repealing it might improve the U.S. deficit." See, Russell A. Green and Tony Payan, "WAS NAFTA GOOD FOR THE UNITED STATES?" June 2017.

file://C:/Users/JK/AppData/Local/Microsoft/Windows/Temporary\%20Internet\%20Files/Content.I E5/51F9Y8AK/BI-pub-NAFTA-062317.pdf . See also, Kallianiotis, Niko J. "America in a Trance" Damiani. https://www.amazon.com/Niko-J-Kallianiotis-America-Trance/dp/8862085958

${ }^{12}$ On 11 December 2001, China officially joined the WTO. Its achievements since then have been truly remarkable. In 2001, China was the sixth largest exporter of goods in the world (fourth, if the European Union is counted as one unit). Since 2009, it has been the world's largest goods exporter, surpassing even the EU bloc from 2014 onwards. See, Petros C. Mavroidis, André Sapir, "China and the WTO: An uneasy relationship", April 29, 2021. https://voxeu.org/article/china-and-wto-uneasyrelationship

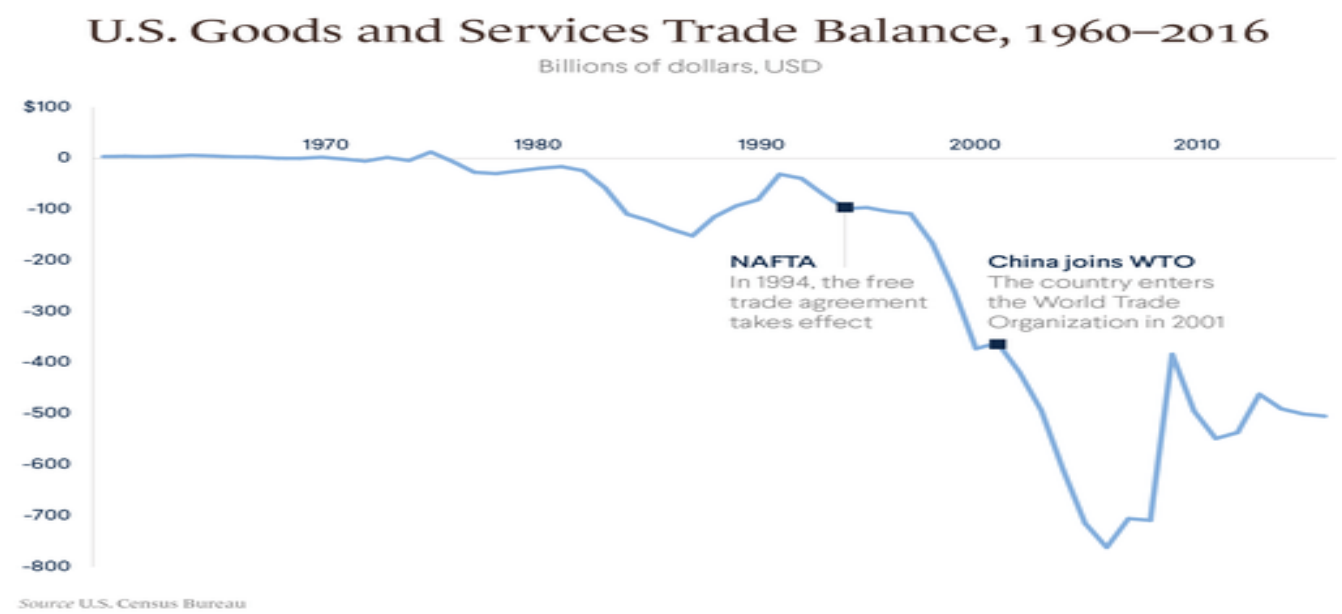

Graph 3: U.S. Current Account

See, Foreign Trade. https://www.census.gov/foreign-trade/balance/c0004.html 
The monetary policy has some small significant effects on the value of the dollar and the trade account. ${ }^{13}$

Then, a combination of monetary and trade policy is necessary to increase the terms of trade (TOT $\uparrow=\frac{P_{M} \uparrow}{P_{X} \downarrow}$ ) and improve the TA. This policy can be more effective through a pure trade one, like, a tariff or a quota or anything else that can affect positively the terms of trade and improve the trade account and consequently, production and employment in the country.

13 See, Table A2: Measuring the correlation $(\rho)$ and testing the causality $(\Rightarrow)$ between the instruments $\left(i_{F F_{t}}, M B\right.$, and $\left.M^{s}\right)$ and the objective variables ( $T A$ and $e$ )

(1) ZIRR (2008:12-2015:11):

$$
\begin{array}{ll}
\rho_{i_{F F}, t a}=-0.358 & i_{F F} \Rightarrow \neq t a \text { and } t a \Rightarrow i_{F F}\left(F=6.068^{* * *}\right) \\
\rho_{i_{F F}, e}=-0.073 & i_{F F} \Rightarrow e\left(F=2.877^{*}\right) \text { and } e \Rightarrow \neq i_{F F} \\
\rho_{m b, t a}=+0.663 & m b \Rightarrow t a\left(F=2.726^{*}\right) \text { and } t a \Rightarrow m b\left(F=3.747^{* *}\right) \\
\rho_{m b, e}=-0.501 & m b \Rightarrow e\left(F=4.433^{* *}\right) \text { and } e \Rightarrow \neq m b \\
\rho_{m, t a}=+0.697 & m \Rightarrow t a\left(F=3.371^{* *}\right) \text { and } t a \Rightarrow m\left(F=4.519^{* *}\right) \\
\rho_{m, e}=-0.625 & m \Rightarrow e\left(F=3.416^{* *}\right) \text { and } e \Rightarrow \neq m
\end{array}
$$

(2) NR (2015:12-2020:12):

$$
\begin{array}{ll}
\rho_{i_{F F}, t a}=+0.111 \quad i_{F F} \Rightarrow t a\left(F=6.286^{* * *}\right) & \text { and } t a \Rightarrow \neq i_{F F} \\
\rho_{i_{F F}, e}=+0.139 & i_{F F} \Rightarrow \neq e \quad \text { and } e \Rightarrow \neq i_{F F} \\
\rho_{m b, t a}=-0.279 & m b \Rightarrow \neq t a \text { and } t a \Rightarrow \neq m b \\
\rho_{m b, e}=+0.297 & m b \Rightarrow e\left(F=5.393^{* * *}\right) \text { and } e \Rightarrow \neq m b \\
\rho_{m, t a}=-0.314 & m \Rightarrow t a\left(F=8.792^{* * *}\right) \text { and } t a \Rightarrow m\left(F=3.180^{* *}\right) \\
\rho_{m, e}=+0.281 & m \Rightarrow \neq e \text { and } e \Rightarrow \neq m
\end{array}
$$

Note: $\mathrm{i}_{\mathrm{FF}}=$ federal funds rate, $\mathrm{ta}=$ trade account, $\mathrm{e}=$ exchange rate, $\mathrm{mb}=$ monetary base, $\mathrm{m}=$ money supply, $\rho_{m, c}=$ correlation coefficients between $m$ and $\left.e, m b \Rightarrow e(F)\right)=$ causality test between $m b$ and $e$ ( $m b$ causes $e$ and F-statistic in parenthesis), $m b \Rightarrow \neq t a=$ no causality between $m b$ and $t a$.

Source: (Kallianiotis, 2021a, Table A2, pp. 107-108). 
The current expansionary monetary policy (zero interest rate since December 2008: $0.00 \% \leq i_{F F} \leq 0.25 \%$ ) and the similar fiscal one with the stimulus money plus the unemployment insurance and the questionable "infrastructure" bill have increase aggregate demand (AD); the COVID-19, the vaccine mandates, the other restrictions, the lockdowns, the resignations of people from their jobs because they were unvaccinated, ${ }^{14}$ the supply chain problems, etc. have reduced aggregate supply (AS). Then, U.S. prices went up (huge inflation) ${ }^{15}$ and a reduction in production have increased imports and reduced exports; and consequently, the trade account has deteriorated $(\mathrm{TA}<0)$. The enormous money supply has also generated a very dangerous bubble in the stock market. ${ }^{16}$ The central bank (Fed) is paying

14 In November 2021, 4.5 million people quitted their jobs; the "great resignation". This will have enormous negative results on our weak economy. (Fox New 1/8/2022).

15 The official inflation is $6.8 \%$ (November 2021), the SGS inflation is $14 \%$, and the average consumer's inflation (cost of living) exceeds $20 \%$. See,

http://www.shadowstats.com/alternate_data/inflation-charts

16 Dow Jones - DJIA - 100 Year Historical Chart

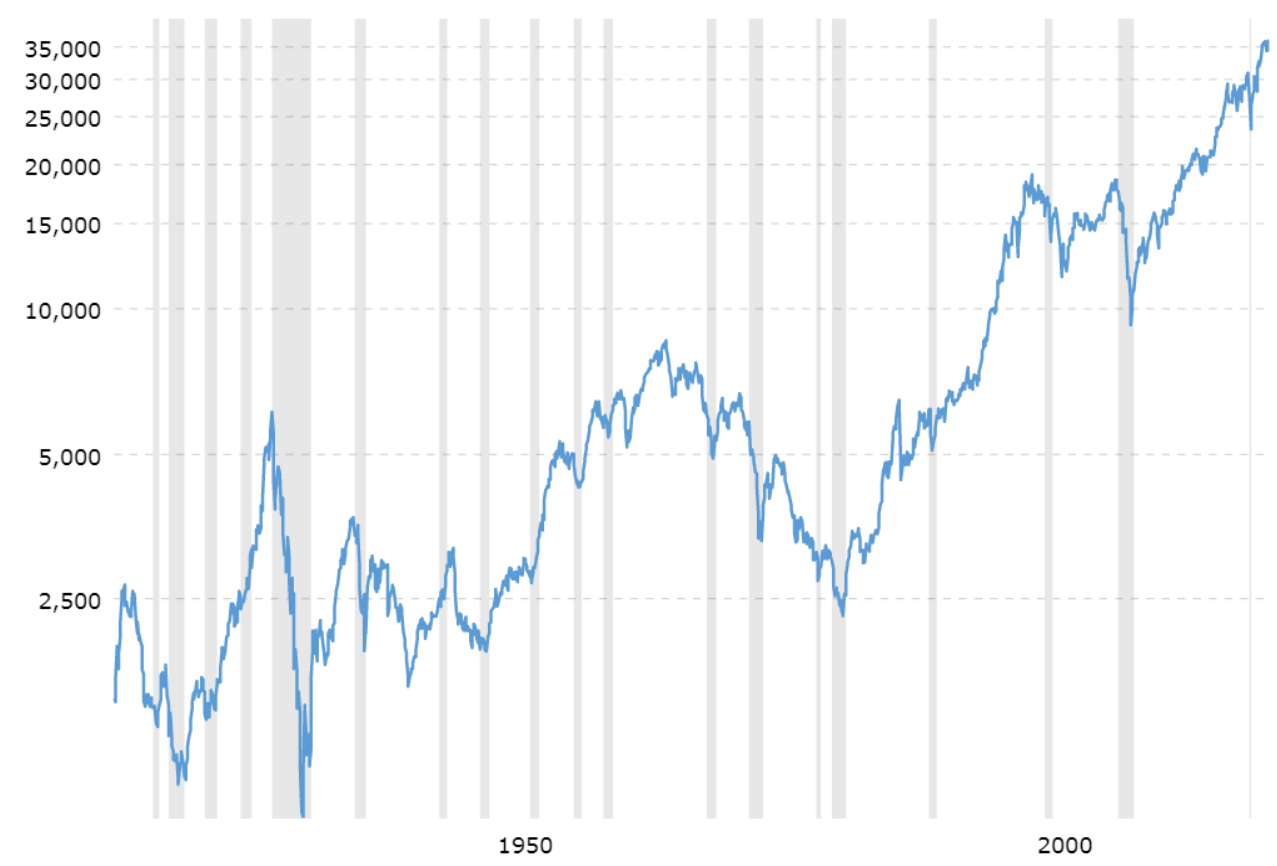

\section{Graph 4: The Dow Jones Industrial Average}

Source: Macrotrends. https://www.macrotrends.net/1319/dow-jones-100-year-historical-chart Also, "WASHINGTON_-President Biden's decision to reappoint Jerome Powell as Federal Reserve chairman, even though some liberal Democrats wanted someone tougher on bank regulations and climate change, and elevate governor Lael Brainard signals continuity on monetary policy but leaves open questions on the direction the central bank will take in regulating Wall Street." See, Fed Picks Leave Open Questions on How Central Bank Will Regulate Wall Street. https://www.wsj.com/articles/fed-picks-leave-open-questions-on-how-central-bank-will-regulatewall-street-11637663401?mod=hp_lead_pos2. 
interest on bank reserves, which costs billions of dollars to taxpayers (bail out cost). The bail in cost to depositors, due to a nominal deposit rate closed to zero since $2008, i_{D}=0.05 \%$, makes the "official" real $r_{D}=-6.95 \%$, is in trillions of dollars. The enormous inflation has reduced consumers' (workers') real income (purchasing power) with an "inflation tax" of $30 \%$.

The country cannot be dependent on foreign production (Chinese goods), but we have to increase domestic production. The uncontrolled outsourcing, the unfair trade, and the anti-social globalization have destroyed the country's social welfare, its independence, and its citizens' wellbeing. The risk of the stock market bubble has to be controlled. Monetary policy is ineffective and socially unfair; it must increase the federal funds rate to reduce inflation and make American products less expensive domestically and for our exports. Real interest rate must be positive $(r>$ $0)^{17}$ and the growth in the stock market to cover only the historic risk premium $(H R P=8.7 \%)$. A $35 \%$ growth in the financial market is just a dangerous deception to the poor citizens (investors). The bail out and bail in costs are completely unethical. Thus, our public policies are inefficient.

\section{Conclusion}

This paper examines the short-run (up to nine months) relationship between the trade account and changes in real exchange rates (TOT) of six countries with respect the U.S. dollar $(\$ / F C)$. It was found that real exchange rate changes have a significant impact on the U.S. trade balance. The empirical results show that there exists a long-run relationship between the trade account and the income (domestic and foreign), the terms of trade (TOT), and volatility of the exchange rate $\left(\sigma^{2}\right)$; also, the residual $\varepsilon^{2}(\mathrm{ARCH})$ and the variance $\sigma^{2}(\mathrm{GARCH})$ have a significant effect on the TAs, Tables $1 \mathrm{a}$ and $1 \mathrm{~b}$.

17 The Fisher equation gives: $i=r+\pi^{e}$, where $\mathrm{r}=0.5 \%, \pi^{\varepsilon}=7 \%$; then, an $\mathrm{i}=7.5 \%$ is fair for the entire economy and it can reduce the bubble in the financial market. Kallianiotis (2019b) rule is an expansion of Taylor's rule by using an extra term, the growth of the financial market $\left(g_{D_{I I A}}\right)$, as follows:

$\bar{i}_{F F_{t}}=\pi_{t}+r_{t}^{*}+\alpha_{\pi}\left(\pi_{t}-\pi_{t}^{*}\right)-\alpha_{u}\left(u_{t}-u_{t}^{N}\right)+\alpha_{D J I A}\left(g_{D J I A_{t}}-g_{D J I A_{t}}^{*}\right)$

where, $g_{D_{J I A_{t}}}=$ the actual growth of the DJIA index, $g_{D J I A_{t}}^{*}=$ the optimal (the bubble prevention) growth of the DJIA $\left(g_{D J I A_{t}}^{*} \leq 7 \% \cong i_{10 Y T B}+5 \%\right.$ or HRP $\left.\cong 8.7 \%\right)$, and $\alpha_{\pi}=0.25, \alpha_{u}=-0.50, \alpha_{D J I A}=0.25$. Kallianiotis rule with June 2021 gives: (1) With official data, the target federal funds rate $\left(\bar{i}_{F F}\right)$ must have been:

$i_{F F}=5.4 \%+1 \%+0.25(5.4 \%-2 \%)-0.50(5.9 \%-4 \%)+0.25(18.22 \%-8.7 \%)=8.68 \%$

(2) With SGS data, the $\bar{i}_{F F}$ should have been:

$i_{F F}=13 \%+1 \%+0.25(13 \%-2 \%)-0.50(25.8 \%-4 \%)+0.25(18.22 \%-8.7 \%)=8.23 \%$ 
The VAR estimations give similar results of the same independent variables on exports and imports between the U.S. and the other six countries (Euro-zone, Canada, U.K., Switzerland, Japan, and Australia), Tables 2a and $2 b$.

The results of this work could be relevant regarding the impact of exchange rate changes on trade account (mostly, U.S. trade deficits). While the short-run effects of changes in the exchange rate on the balance of trade of a county may be perverse (J-curve), in the long-run the impact of exchange rate changes on trade volumes are expected to be sufficiently large; so a depreciation of the domestic currency will improve the country's trade account. Number of factors may explain the persistence of the J-curve effect. In the short-run, a combination of price and volume effects, following a currency depreciation may increase a country's spending on imports by more than it increases its export earnings, thus accounting for the observed J-curve effect; then

a devaluation will likely result in an initial deterioration of the trade balance. Furthermore, differences in the degree of the restrictiveness of devaluing countries trade regimes also may affect the duration of the J-curve effect.

Finally, as far as policy implications are concerned, it is important for the country to use public policies (monetary, fiscal, and trade) to improve the domestic economy and the social welfare of its citizens. So far, the public policies are ineffective and inefficient. The economy has some structural problems and must be considered as soon as possible, otherwise the country will lose completely its competitiveness, as it has already lost its manufacturing output compared with China. ${ }^{18}$ The liberal views of globalization and of "nothing matters" are going to lead the country to a permanent negative trend. The trade must be fair among the nations and in favor of the domestic economy and not "the allies first" policy.

ACKNOWLEDGMENTS. I would like to acknowledge the assistance provided by Julia V. Betti and Janice Mecadon. Financial support (professional travel expenses, submission fees, etc.) are provided by Provost's Office (Faculty Travel Funds, Henry George Fund, and Faculty Development Funds). The usual disclaimer applies. Then, all remaining errors are mine.

18 See, Mark J. Perry, "Chart of the day: China is now world's No. 1 manufacturer". https://www.aei.org/carpe-diem/chart-of-the-day-china-is-now-worlds-no-1-manufacturer/ 


\section{References}

[1] Backus, D.K., Kehoe, P.J., Kydland, F.E. (1994), "Dynamics of the trade balance and the terms of trade: The J-curve?" The American Economic Review, March, 84(1):84-103

[2] Bahmani-Oskooee, M. (1991), "Is there a long-run relation between the trade balance and the real effective exchange rate of LDCs?", Economics Letters 36: 403-407

[3] Bera, A.K., Higgins, M.L. (1993), "ARCH models: Properties, estimation and testing”, Journal of Economic Surveys , December. 7(4): 305-366

[4] Bollerslev, T. (1986), "Generalized autoregressive conditional heteroscedasticity", Journal of Econometrics , 31: 307-327

[5] Bollerslev, T. (1987), "A conditional heteroskedastic time series model for speculative prices and rates of return", The Review of Economics and Statistics, August, 69(3): 542-547

[6] Campbell, J.Y., Shiller, R.J. (1987), "Cointegration and tests of present value models", Journal of Political Economy, October, 95(5): 1062-1088

[7] Chou, R. (1988), "Volatility persistence and stock valuation: Some empirical evidence using GARCH", Journal of Applied Econometrics, 3: 279-294

[8] Engle, Robert F., David M. Lilien, and Russell P. Robins, (1987), "Estimating Time Varying Risk Premia in the Term Structure: The ARCH-M Model", Econometrica, 55, 391-407.

[9] Himarios, D. (1989), "Do devaluations improve the trade balance? The evidence revisited", Economic Inquiry, 27: 143-168

[10] Kallianiotis, John N. (2021a), "The New Monetary Policy: Its Social Cost and Benefits", Chapter 1, in Progress in Economics Research, Volume 46, Albert Tavidze (Editor), pp. 1-111, Hauppauge, N.Y.: Nova Science Publishers, May 2021, ISBN: 978-1-53619-704-4 (eBook) and ISBN: 1549-1552. https://novapublishers.com/shop/progress-in-economics-research-volume-46/

[11] Kallianiotis, I. N. (2021b), "Ethics in Finance, Public Policies, and Institutions: The Latest Financial and Social Crises", International Journal of Managerial Studies and Research (IJMSR), Volume 9, Issue 1, 2021, pp. 13-41. https://arcjournals.org/international-journal-of-managerial-studies-andresearch/volume-9-issue-1/,https://arcjournals.org/pdfs/ijmsr/v9-i1/3.pdf , file:///C:/Users/R97719842/Downloads/02200133\%20(2).pdf

[12] Kallianiotis, J. N. (2019a), Foreign Exchange Rates and International Finance, Hauppauge, N.Y.: Nova Science Publishers, October 2019, ISBN: 978-153616-550-0.

https://novapublishers.com/shop/foreign-exchange-rates-and-internationalfinance/

[13] Kallianiotis, I.N. (2019b), "Monetary Policy, Real Cost of Capital, Financial Markets, and the Real Economic Growth", Journal of Applied Finance \& Banking, Vol. 9, No. 1, pp. 75-118. 
http://www.scienpress.com/journal_focus.asp?main_id=56\&Sub_id=IV\&Issu $\underline{\mathrm{e}=810815}$ http://www.scienpress.com/Upload/JAFB/Vol\%209 1 4.pdf

[14] Kallianiotis, John N. (2018), The European Union and its Debt Crises: The Deception of the Greeks, Hauppauge, N.Y.: Nova Science Publishers, August 2018, ISBN: 978-1-53614-067-5. https://novapublishers.com/shop/theeuropean-union-and-its-debt-crises-the-deception-of-the-greeks/

[15] Kallianiotis I. N. (2016), "Factors Affecting the Exchange Rate Risk Premium", Journal of Applied Finance \& Banking, Vol. 6, No. 6, November, pp.

http://www.scienpress.com/journal_focus.asp?main_id=56\&Sub_id=IV\&Issu e=1945 and http://www.scienpress.com/Upload/JAFB/Vol\%206_6_3.pdf

[16] Kallianiotis, J. N. (2013a), International Financial Transactions and Exchange Rates: Trade, Investment, and Parities, Theories, and Practices, Palgrave Macmillan, December 2013, pages 332, ISBN: 978-1-137-35815-8.

http://us.macmillan.com/internationalfinancialtransactionsandexchangerates/J ohnNKallianiotis

[17] Kallianiotis, J. N. (2013b), Exchange Rates and International Financial Economics: History, Theories, and Practices, Palgrave Macmillan, October 2013, pages 312, ISBN: 978-1-137-28322-1.

http://us.macmillan.com/exchangeratesandinternationalfinancialeconomics/Jo hnNKallianiotis

[18] Marquez, J. (1991), "The dynamics of uncertainty or the uncertainty of dynamics: Stochastic J-curves", The Review of Economics and Statistics, February, LXXIII(1): 125-133

[19] Marwah, K., Klein, L.R. (1996), "Estimation of J-curves: United States and Canada", Canadian Journal of Economics, August, XXIX(3):523-539

[20] Pozo, S. (1992), "Conditional exchange-rate volatility and the volume of international trade: Evidence from the early 1900s", The Review of Economics and Statistics, May, $\operatorname{LXXIV(2):~325-329~}$

[21] Rose, A.K., Yellen, J.L. (1989), "Is there a J-curve?", Journal of Monetary Economics, July, 24(1): 53-68

[22] Rose, A.K. (1991), "The role of exchange rate in a popular model of international trade: Does the Marshall-Lerner condition hold?", Journal of International Economics, May, 30(3/4): 301-316

[23] Schwaiger, W.S.A. (1995), "A note on GARCH predictable variances and stock market efficiency', Journal of Banking and Finance, August, 19: 949953

[24] Singh, Tarlok (2004), “Testing J-curve hypotheses and analyzing the effect of exchange rate volatility on the balance of trade in India", Empirical Economics, pp. 227-245.

[25] Smith, P., S. Soresen, and M. Wickens (2003), "Macroeconomic Sources of Equity Risk", CEPR Discussion Paper No. 4070. 


\section{Appendix}

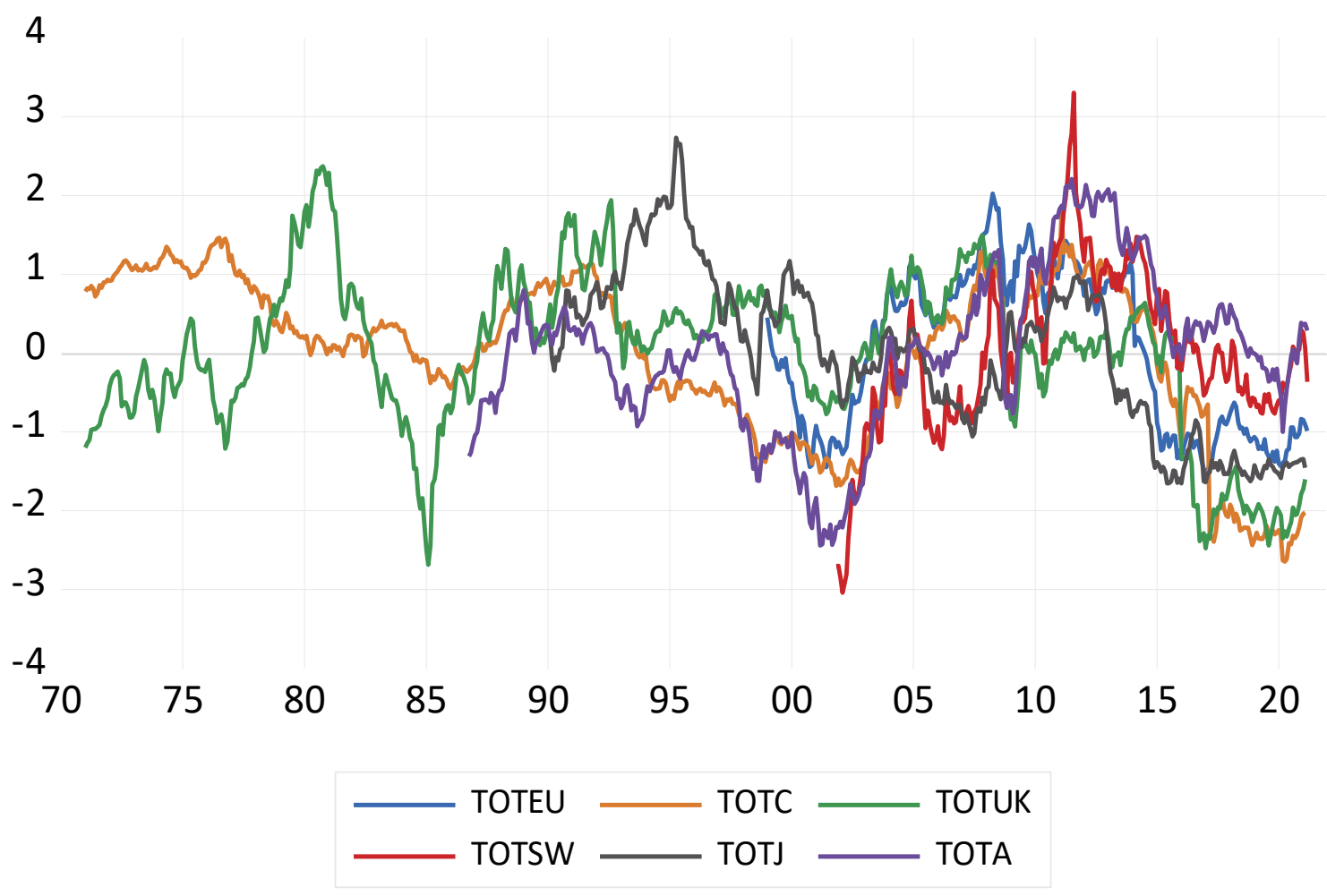

Graph A1: Terms of Trade between U.S. and Foreign Countries

Note: $T O T E U=$ U.S. TOT with Euro-zone, $T O T C=$ TOT with Canada, $T O T U K=$ TOT with U.K., TOTSW $=$ TOT with Switzerland, TOTJ = TOT with Japan, TOTA = TOT with Australia. 